\title{
The Relationship Between Role Conflict As Internal Barrier And Career Advancement Among Women In Banking Sector
}

\author{
Shahida Mansor \\ Kolej Universiti Islam Melaka, Melaka \\ shahida@kuim.edu.my
}

Hazelena Dewi Fatahul Ariffin
Department of Human Potential Management, Kolej Universiti Islam Antarabangsa Selangor, Bandar Sri Putra Bangi, 43000 Kajang, Selangor, Malaysia
hazelena@kuis.edu.my

Mohd Hakimi Md Baharudin

Department of Human Potential Management, Kolej Universiti Islam Antarabangsa Selangor, Bandar Sri Putra Bangi, 43000 Kajang, Selangor, Malaysia

mohdhakimi@kuis.edu.my

\section{Zulhizzam Hamzah}

Department of Human Potential Management, Kolej Universiti Islam Antarabangsa Selangor, Bandar Sri Putra Bangi, 43000 Kajang, Selangor, Malaysia

zulhizzam@kuis.edu.my

\begin{abstract}
The main purpose of this study is to identify the relationship between role conflict as internal barrier and career advancement among women in banking sector. In this quantitative study, a set of questionnaire focusing on women executives was used for data collection. A total number of 263 women employees among the women executives in banking sector were selected to participate in the study. The research findings shown that, there was a significant effect of roleconflict on career advancement among women. It is recommended employer should provide training that can improve women executives' time management.
\end{abstract}

Keywords: Career advancement, barriers in career advancement, internal barrier, aspiration

\section{Introduction}

Rapid growth of technology has been widely discussed by everyone. Technology advancement has always be the first thing when it comes to organization (Samulewicz, 2012). Technology has been the key to success for the organizations to achieve their goals. It is because; recently everyone has been bonded with technology (Wesley, 2009). Technology advancement has created the trend where organizations go paperless. The medium of communication in business transactions are mainly based on the internet, emails, social networking and many more. These medium have helped the organizations to shorten the time it takes to do a business transactions, thus help organization to achieve their goal. When the length of services become shorten, employees that work in the organizations are assumed to be fast, responsive and dynamic in order to catch up with the rapid growth of technology.

This is where the employees and the organizations need to look at the career advancement within them. As a result, the term career advancement will appear in individual's working life. Career advancement is about growth and development of career. Career advancement is a process of developing, improving and broadening knowledge, skills, and abilities (Pompper, 2011). Therefore, from this point of view, it can be seen that career advancement is one of important factor in an organization. Organizations are the place where employees find ways of advancing in their career ladder. Career advancement is important because it helps the employees to gain recognition 
and build up reputations. The current situation has made the employees aware of the importance of knowledge, skills and abilities in order to keep on survive in the organization. This helps the organization improve their human capital. Back to the 1980s, the employees are given only specific task because it was the era of traditional work, which means, men will do the men's work and vice versa to women (Hartl, 2004). Nevertheless, starting in the 1990s, where the technology started to enter the career life, men and women were treated equally (Burke, 2006). There were no more men's or women's work.

Career advancement requires participation from both the employers and employees, in order for it to commence successfully. Career advancement is all about the ways in motivating employees and the process of enhancing satisfaction in career life. According to Jenny (2011), men and women possess different desires and needs. Therefore, there are also differences between men's and women's career advancement. Men are more favourable to be appointed in the top management positions instead of women employees.

A study in the United Kingdom showed that in a male-dominated culture, men tend to be recruited and promoted faster than female. This study provided clear evidence that this culture has impeded women's career progress in banking. The result of this study also showed that $48 \%$ of women agreed that barriers to progression for women existed in their organization and $37 \%$ of men agreed. Thus, the number of women who have advanced to top management level is still low worldwide and women tend to remain at lower-ranking and lower-paying jobs (Tinklin et al., 2005).

Since 1970s, family was categorized by traditional role which, women with wife/mother role and men as the breadwinner and protector. Fundamentally, women were bound to traditional family roles while men interpreted by their work. According to Miller (2008), recently, the traditional role is invalid. In fact, women with dual career, which focuses on family, and career currently replace the women that bound to traditional roles.

Azmi (2012) notes that lately, there is an increased on the number of women entering the labour force and it has changed the women status in society. So far, Stockdale (2004) notes that the career advancement of women is regarded to be diverse to that of men. This is mostly in line to differences in behaviours, attitudes, and the way of how women socialized. Studies on career advancement have concentrated mainly on matters provoking men, supposing that comparable matters provoke women (Heimler, 2012). Nonetheless, in line to the fact that many women are now seeking to senior management positions, researchers have lately begun to examine some of the career related barriers women encounter as they enter conventionally male dominated careers (Litzky, 2007).

As seen recently, even though there is an increased in the number of women participating in the labour force, yet, women's representation in the top management positions is still lacking. This shows that there is a blockage in women's career advancement. Career advancement is important in organizations and to employees. Career advancement is one of the way for the organization to attract and retain their human talent (Rudman, 2008). Career advancement is a process which employees will go through an additional of responsibilities and tasks on the way to climb up the career ladder.

Career advancement also shows that, organization is committed in putting their trust on the employees. This is how organization shows appreciation to their employees besides the salary and monetary benefits. In organization, career advancement is like killing two birds with a stone where, besides retaining the employees the organization also able to maintain their productivity, and consequently increase the productivity. Career advancement is important because, it helps both of the employers and employees. That is why, it needs to be reviewed, planned, and evaluated, so that the career advancement can be well measured. 


\section{Barriers in Career Advancement}

Career barriers are defined as events or conditions either within the person's environments that make career advancement difficult (Ghani, 2006). Discussions on barriers differentiate between two types, namely, internal and external barriers (Swanson, 1997). It has been noted that as individuals realize and identify occupational barriers, they may deal with the perceived reality by comprising their occupational goals (Hayfaa Tlaiss, 2010). According to Khapova (2007), barriers are concepts that explain the discrepancy between women's abilities and their achievements. According to Maimunah (2008), individual barriers are the barriers that face by the people from within themselves, while, organizational barriers are the barriers that employees face from the organization itself (Hayfaa Tlaiss, 2010). However, in this study, the researcher will on focus on aspiration as internal barrier in career advancement among women.

\section{Role Conflict}

Hamidi (2013) states that role conflict is a conflict among the roles corresponding to two or more statuses. It occurs when people are confronted with incompatible role expectations in the various social statuses they occupy. In this study, role conflict is focusing on women that have dual career which, her career at the workplace and her career at home.

Burke (2006) explains role overload as the inability to satisfy all role expectations in the time available, despite recognizing the legitimacy of all demands. Role conflict is a form of inter role conflict in which the role pressures from work and family domains are mutually incompatible, or participation in one role is more difficult due to participation in another role (Chinchilla, 2006).

Kang (2005) found that successful women who worked extremely hard in developing their careers do not have the psychological or physical energy left to invest in their personal lives. In a study conducted with television news anchors it was found that more than half of the respondents experienced conflict between their roles as wife/mothers and that of professional newscasters (Ghani,
2006). To manage the conflict between their work and family roles, women classified their lives as working late to avoid taking work home. According to Samulewicz (2012), he points out that role conflict leads to anxiety, fatigue, stress, and emotional depletion. In addition, he also adds that role overload is prevalent in most women, especially women in management.

According to (Jogulu, 2011), internal barriers are the barriers that came from the employees inside. It is the barriers that in the control of employees whereby it is all about the self-concept and self-perception of the employees. Employees that tend to have negative perception, they tend to face the internal barriers (Darioly, 2010). From a previous study done in a manufacturing industry by Maimunah (2008), 150 out of 208 respondents claimed that family support as the factor that stop them from advancing in the career. This study is supported by Al-Ahmadi (2011) that surveyed employees in the health industry in the Middle East that showed role-conflict has affected the career advancement of women employees. This shows that it has effect on the career advancement among women.

\section{Research Design}

The data for the study were collected through a well-structured questionnaire, which was prepared and distributed among the women executives who worked in the banking sectors in Kuala Lumpur.A total of 350 copies of questionnaires were administered within the scope of selected banks. Having sorted the returned questionnaires, only 263 copies of questionnaires were valid to be used for analysis. The data obtained from this study were presented using table with specifications made on the amount of questionnaire distributed. The results were obtained based on the opinions of the respondents. 
Data Analysis Method

\section{Analysis}

Description

Reliability An evaluation that been used in a

study to measure the stability and

Validity of the items that are

available in the questionnaire in

order to obtain the best result

out of it

Descriptive To describe and get a summary of inform from the data obtained

through the population or sample

Correlation The method used to identify the relation between the variables

Regression Simple linear regression is a method used to obtain a straight line at the distributed value that can be used at the collected information

\section{Reliability}

Reliability is an evaluation that been used in a study to measure the stability and validity of the items that are available in the questionnaire in order to obtained the best result out of it (Sekaran, 2003). Internal consistency reliability with the Cronbach's Alpha coefficients is used in this study. In this study, the co-efficient of the role-conflict is 0.823 and career advancement is 0.782 .

\section{Pearson's Correlation}

According to Sekaran (2003), the main task that need to be done by the researcher before obtaining the mean and the standard deviation for the independent and dependent variable is to know how does the variables related to each other. Therefore, correlation has been tested towards the barriers and career advancement and also self-esteem and career advancement in order to prove that there is a significant relationship among the three variables.

Table 1:

1: Pearson's

\section{Correlation}

\begin{tabular}{|l|l|}
\hline \multicolumn{2}{|l|}{ Pearson's Correlation } \\
\hline Variable & Correlation \\
\hline Role Conflict & $0.339 * *$ \\
\hline & \\
\hline
\end{tabular}
0.01 level (2-tailed)

From Table 1 , the correlation is 0.339 which means that there is a significant relationship between role-conflict and career advancement.

\section{Discussions}

The findings showed that there is a significant relationship between role-conflict and career advancement among women. It shows that role-conflict has a positive relationship with career advancement among women. In addition, role conflict dimension also contribute to the high level of internal barrier experienced by the women executives. Based on the findings, women executives find it difficult to travel if required by work conditions because of family and personal circumstances. This shows that women executives are having a difficult time in managing their priorities either family or career. This findings supported a study conducted by Ghani (2011) with television news anchors. The study reported that more than half of the respondents experienced conflict between their roles as wife/mothers and professional newscasters. Kang (2005) found that successful women who worked extremely hard in developing their careers do not have the psychological or physical energy left to invest in their personal lives.

\section{The Limitation of the Study}

Like the previous studies, the researcher also faces the internal factors that affect and influence the feedback of 
the respondents. This is due to the human nature that easily affected by the emotions and the surroundings and also personal commitments that are difficult to be controlled by the researcher. Plus, the quantitative analysis that been used in this study does not explain the matters relating to emotions, feelings, reactions and perceptions from the respondents while they answer the questionnaire. Therefore, it cannot portray banking sector as a whole. Next, the limitation that been faced by the researcher is the data collection aspect. The data collected is related only to the barriers and career advancement. However, the theories, models and instruments used by the researcher need to be analyse then will be choose to ensure that the items selected are the ones that are up-to-date.

\section{Conclusion}

Career advancement is one of the important elements that need to be instilled in each employee. The employer should play their role in coping and help the employees in facing the barriers they encounter in the career life. Instead of the employer, the employees should also be proactive in the organization. Interaction between the employer and the employees is very important.

\section{References}

Abdul Ghani Azmi, I. (2011). Career Advancement Barriers in Malaysian Federal Public Service. International Conference on Financial Management and Economics, 11.

Al-Ahmadi, H. (2011). Challenges Facing Women Leaders in Saudi Arabia. Human Resource Development International, 14(2), 149-166.

Burke, R. J. (2006). Organisational Practices Supporting Women's Career Advancement and Their Satisfaction and Well-Being in Turkey. Women In Management Review, 21(8), 610-624.

Chinchilla, N. (2006). Career Inhibitors and Career Enablers for Executive Women. Working Paper, 632.

Darioly, A. (2010). Facing an Incompetent Leader: The Effects of a Nonexpert Leader on Subordinates' Perception and Behaviour. European Journal of Work and Organizational Psychology, 20(2), 239265.

Ghani, Z. A. (2006). Kerjaya Wanita Islam Dalam Bidang Penyiaran: Cabaran Dan Prospek. Jurnal Usuluddin, 23-24.

Hamidi, K. A. (2013). Politik Gender: Peranan Wanita Dan Proses Politik Di Malaysia-Jepun: Halangan Dan Prospek. International Conference on Social Science Research.
Hartl, K. (2004). The Expatriate Career Transition and Women Managers' Experiences. Women In Management Review, 19(1), 40-51.

Jenny, M. H. S. (2011). Exploring Success Factors in Top Careers in the Netherlands Advances in Hospitality and Leisure (Vol. 7, pp. 3-27): Emerald Group Publishing Limited.

Jogulu, U. (2011). Women Managers' Career Progression: An Asia Pacific Perspective. Gender in Management: An International Journal, 26(8), 590603.

Kang, H.-R. (2005). Women in Management in South Korea: Advancement or Retrenchment? Asia Pacific Business Review, 11(2), 213-231.

Krejcie, R. V., \& Morgan, D. W. (1970). Determining Sample Size for Research Activities. Educational and psychological measurement, 30(3), 607-610.

Maimunah, I. (2008). Barriers to Career Progression Faced by Women: Evidence from a Malaysian Multinational Oil Company. Women In Management Review, 23(1), 51-66.

Pompper, D. (2011). Fifty Years Later: Mid-Career Women of Color against the Glass Ceiling in Communications Organizations. Journal of Organizational Change Management, 24(4), 464486.

Rudman, L. A. (2008). Backlash Effects for Disconfirming Gender Stereotypes in Organizations. Research in Organizational Behavior, 28(0), 61-79.

Samulewicz, D. (2012). Barriers to Pursuing Careers in Science, Technology, and Engineering for Women in the United Arab Emirates. Gender, Technology and Development, 16(2), 125-152.

Sekaran, U. (2003). Research Methods for Business: A Skill Building Approach: New Delhi: John Wiley and Son Inc.

Wesley, S. M. (2009). The Effect of Gender and Race on Career Advancement: A Study of Minority Women in Executive-Level Positions within Nonprofit Organizations. Unpublished 3339302, Capella University, United States -- Minnesota. 